\title{
PERENCANAAN SISTEM DRAINASE DI DAERAH ALIRAN SUNGAI (DAS) KALI DAPUR / OTIK SEHUBUNGAN DENGAN PERKEMBANGAN KOTA LAMONGAN
}

\author{
Ichsan Rizkyandi, Bambang Sarwono, Yang Ratri Savitri. \\ Jurusan Teknik Sipil, Fakultas Teknik Sipil dan Perencanaan, Institut Teknologi Sepuluh Nopember (ITS) \\ J1. Arief Rahman Hakim, Surabaya 60111 Indonesia \\ e-mail : bambang_s@ce.its.ac.id
}

\begin{abstract}
Abstrak-Lamongan yang terus berkembang dari sebuah kabupaten menjadi sebuah kota menyebabkan Lamongan melakukan pembenahan di bidang infrastruktur. Bidang infrastruktur yang dibenahi salah satunya ialah sistem drainase. Pembenahan sistem drainase dilakukan karena banjir masih sering terjadi ketika hujan terjadi. Perencanaan sistem drainase ini dilakukan sehubungan dengan adanya Rencana Tata Ruang Wilayah (RTRW) Lamongan tahun 2011 - 2031. Perbedaan perencanaan pada tahun 2011 dan pada tahun 2031 dapat dilihat dari nilai koefisien pengalirannya. Perbedaan nilai koefisien pengaliran terjadi akibat dari adanya perubahan fungsi tata guna lahan di Lamongan pada tahun 2011 dan pada tahun 2031.

Kali Dapur / Otik sebagai salah satu dari empat Kali yang berperan penting dalam sistem drainase Lamongan akan dievaluasi / direncanakan kembali. Evaluasi terhadap Kali Dapur / Otik bertujuan untuk mengetahui kapasitas penampang Kali Dapur / Otik dalam menampung debit rencana. Evaluasi dilakukan pada penampang Kali Dapur sepanjang $\pm 5,5 \mathrm{~km}$. Dari hasil evaluasi yang dilakukan, penampang eksisting Kali Dapur / Otik belum mampu menampung debit banjir sehingga perlu dilakukan normalisasi. Normalisasi dilakukan dengan cara merapikan bentuk penampang dan kemiringan sungai tanpa mengubah elevasi dasar penampang eksisting di hilir Kali Dapur / Otik. Hal ini dikarenakan perencanaan normalisasi Kali Dapur / Otik tidak dilakukan secara keseluruhan melainkan hanya sepanjang $\pm 5,5 \mathrm{~km}$. Oleh karena itu, normalisasi sepanjang $\pm 5,5 \mathrm{~km}$ dilakukan tanpa mengubah elevasi dasar penampang di hilir dengan tujuan agar tidak memengaruhi bentuk dasar penampang Kali Dapur / Otik secara keseluruhan. Selain itu, normalisasi Kali Dapur / Otik tidak dilakukan dengan memperlebar penampang dikarenakan adanya pemukiman dan jalan raya di sisi kanan maupun sisi kiri Kali Dapur / Otik sepanjang $\pm \mathbf{5 , 5}$ km.

Setelah normalisasi dilakukan, penampang Kali Dapur / Otik sudah mampu menampung debit banjir yang terjadi. Namun, penampang normalisasi belum memenuhi syarat tinggi jagaan sebesar $0,5 \mathrm{~m}$. Oleh karena itu, diperlukan suatu tindakan penyelesaian untuk membantu Kali Dapur dalam memenuhi syarat tinggi jagaan. Tindakan yang dilakukan ialah dengan merencanakan suatu boezem di saluran Primer Sidoharjo dengan kebutuhan kapasitas tampung sebesar $359408,74 \mathrm{~m}^{3}$.
\end{abstract}

Kata kunci-Kali Dapur, Kali Otik, Drainase

\section{PENDAHULUAN}

Rencana pembangunan Lamongan menjadi sebuah kota menyebabkan Lamongan segera melakukan beberapa pembenahan di bidang infrastruktur. Salah satu pembenahan yang dilakukan ialah sistem drainase..

Pada tugas akhir ini, yang menjadi obyek perencanaan drainase adalah Kali Dapur / Otik sepanjang $\pm 5,5 \mathrm{~km}$. Untuk mengantisipasi perkembangan Kota Lamongan dalam beberapa tahun ke depan, maka perencanaan drainase harus memperhatikan Rencana Tata Ruang Wilayah (RTRW). RTRW Kota Lamongan yang digunakan ialah RTRW tahun 2011 hingga tahun 2031. Dengan adanya RTRW, maka dapat diketahui perubahan fungsi tata guna lahan yang sangat penting dalam perhitungan debit banjir.

\section{A. Rumusan Masalah}

Permasalahan yang akan dibahas dalam tugas akhir ini adalah sebagai berikut :

1. Berapa luas daerah aliran sungai (DAS) Kali Dapur / Otik?

2. Berapa nilai koefisien pengaliran (C) pada tahun 2011 dan tahun 2031 akibat adanya perubahan fungsi tata guna lahan?

3. Berapa debit banjir pada tahun 2011 dan tahun 2031 akibat adanya perubahan fungsi tata guna lahan?

4. Bagaimana kapasitas penampang eksisting di Kali Dapur pada tahun 2011 dan tahun 2031 ?

5. Tindakan apa yang perlu dilakukan untuk mengatasi permasalahan banjir di Kali Dapur? 


\section{METODOLOGI}

A. Diagram Alir Metodologi

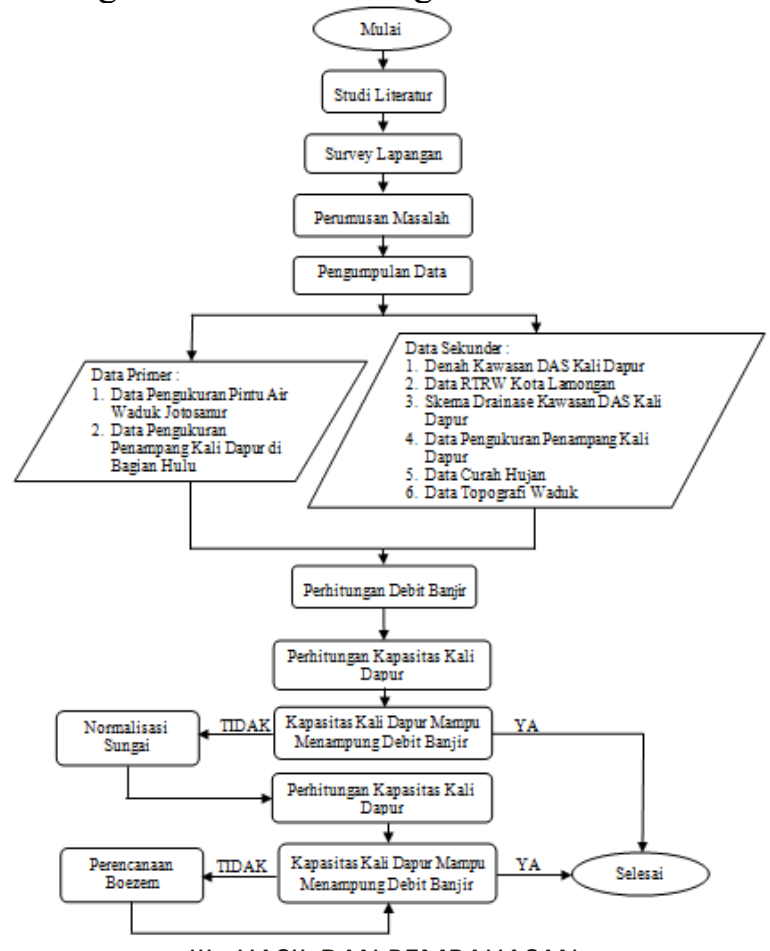

III. HASIL DAN PEMBAHASAN

B. Perhitungan Luas DAS Kali Dapur

Tabel 1. Luas DAS dari tiap saluran yang menuju Kali Dapur

\begin{tabular}{|c|c|c|}
\hline No & Nama Saluran & Luas DAS $\left(\mathrm{m}^{2}\right)$ \\
\hline 1 & Primer G. Boyo Untung & $935.810,79$ \\
\hline 2 & Primer Delanggu & $5.429 .999,05$ \\
\hline 3 & Primer Andan Wangi & $1.216 .043,06$ \\
\hline 4 & Sekunder Pahlawan & $177.300,34$ \\
\hline 5 & Primer Sumargo & $504.788,99$ \\
\hline 6 & Primer Kalianyar & $1.254 .317,89$ \\
\hline 7 & Primer Sidoharjo & $4.183 .475,87$ \\
\hline 8 & Primer Wajik & $465.505,00$ \\
\hline 9 & Primer Kramat & $11.475 .936,17$ \\
\hline 10 & Sekunder Kramat & $13.645,92$ \\
\hline 11 & Primer Mantup $\left(\mathrm{A}_{1}{ }^{\prime}-\mathrm{A}^{\prime}\right)$ & $1.160 .376,07$ \\
\hline 12 & Primer Tikung $\left(\mathrm{A}_{3}-\mathrm{A}_{2}-\mathrm{A}_{1}-\mathrm{A}\right)$ & $6.510 .540,19$ \\
\hline
\end{tabular}

Dari perhitungan luasan DAS pada tabel 1 maka dapat diketahui bahwa Kali Dapur / Otik memiliki luas total DAS sebesar $\pm 32.797 .378,61$ $\mathrm{m}^{2}$.

\section{B. Perhitungan Distribusi Hujan}

Pemilihan jenis distribusi yang sesuai dapat dilihat pada tabel 2.
Tabel 2. Pemilihan Jenis Distribusi yang Sesuai

\begin{tabular}{|c|c|c|c|}
\hline Jenis Distribusi & Syarat & Hasil & Keterangan \\
\hline \multirow{2}{*}{ Normal } & $\mathrm{Cs} \approx 0$ & $\mathrm{Cs}=0,528$ & \multirow{2}{*}{$\begin{array}{c}\text { Kurang } \\
\text { memenuhi }\end{array}$} \\
\hline & $\mathrm{Ck}=3$ & $\mathrm{Ck}=2,662$ & \\
\hline \multirow{2}{*}{ Gumbel Tipe I } & $\mathrm{Cs} \leq 1,1396$ & $\mathrm{Cs}=0,528$ & \multirow{2}{*}{ Memenuhi } \\
\hline & $\mathrm{Ck} \leq 5,4002$ & $\mathrm{Ck}=2,662$ & \\
\hline Log Pearson Tipe III & $\mathrm{Cs} \neq 0$ & $\mathrm{Cs}=0,123$ & Memenuhi \\
\hline \multirow{2}{*}{ Log Normal } & $\mathrm{Cs} \approx 3 \mathrm{Cv}+\mathrm{Cv}^{2}=3$ & $\mathrm{Cs}=0,123$ & \multirow{2}{*}{$\begin{array}{c}\text { Tidak } \\
\text { Memenuhi }\end{array}$} \\
\hline & $\mathrm{Ck}=5,383$ & $\mathrm{Ck}=2,546$ & \\
\hline
\end{tabular}

Pada tabel 2, dapat dilihat bahwa terdapat 2 jenis distribusi yang dapat digunakan. Dari kedua jenis distribusi tersebut dilakukan uji kecocokan yaitu uji Chi Kuadrat dan uji Smirnov - Kolmogorov untuk menentukan distribusi mana yang paling cocok untuk digunakan. Rekapitulasi uji Chi Kuadrat dan uji Smirnov - Kolmogorov untuk distribusi Gumbel Tipe I dan Log Pearson Tipe III dapat dilihat pada tabel 3 .

Tabel 3. Rekapitulasi Uji Kecocokan

\begin{tabular}{|l|c|c|c|c|c|c|c|c|}
\hline \multirow{2}{*}{ Jenis Distribusi } & \multicolumn{4}{|c|}{ Uji Chi Kuadrat } & \multicolumn{4}{c|}{ Uji Smirnov Kolmogorov } \\
\cline { 2 - 9 } & $\mathrm{Xh}^{2}$ & & $\mathrm{X}_{\mathrm{kr}}^{2}$ & Ket. & $D_{\text {maks }}$ & & Do & Ket. \\
\hline Gumbel Tipe I & 2.8 & $<$ & 7.815 & OK & 0.095 & $<$ & 0.29 & OK \\
\hline Log Pearson Tipe III & 4 & $<$ & 7.815 & OK & 0.308 & $>$ & 0.29 & NOT OK \\
\hline
\end{tabular}

Dari tabel 3, maka digunakan distribusi gumbel tipe I untuk menghitung hujan rencana. Berikut adalah perhitungan hujan rencana dengan menggunakan distribusi Gumbel Tipe I :

$\mathrm{X}_{2}=76,205+\frac{20,193}{1,0628}(0,3065-0,5236)=$ $72,08 \mathrm{~mm}$

$\mathrm{X}_{5}=76,205+\frac{20,193}{1,0628}(1,4999-0,5236)=$ $94,76 \mathrm{~mm}$

$\mathrm{X}_{10}=76,205+\frac{20,193}{1,0628}(2,2504-0,5236)=$ $109,01 \mathrm{~mm}$

$\mathrm{X}_{20}=76,205+\frac{20,193}{1,0628}(2,9702-0,5236)=$ $122,69 \mathrm{~mm}$

$\mathrm{X}_{25}=76,205+\frac{20,193}{1,0628}(3,1250-0,5236)=$ $125,63 \mathrm{~mm}$

$\mathrm{X}_{50}=76,205+\frac{20,193}{1,0628}(3,9019-0,5236)=$ $140,39 \mathrm{~mm}$

$\mathrm{X}_{100}=76,205+\frac{20,193}{1,0628}(4,6001-0,5236)=$ $153,66 \mathrm{~mm}$

Pada Tugas Akhir ini, digunakan nilai perhitungan hujan rencana dengan periode ulang 10 tahun $\left(\mathrm{X}_{10}\right)$ sebesar 109,01 mm. 
Perencanaan Sistem Drainase di Daerah Aliran Sungai (DAS) Kali Dapur/ Otik Sehubungan dengan Perkembangan Kota Lamongan

C. Analisa Debit

Analisa debit banjir pada Tugas Akhir ini dibagi menjadi 2 yaitu analisa debit banjir pada tahun 2011 dan debit banjir pada tahun 2031. Debit banjir yang dihitung ialah debit banjir di saluran Primer Tikung, saluran Primer Mantup, saluran sekunder Kramat, saluran Primer Kramat, saluran Primer Wajik, saluran Primer Sidoharjo saluran Primer Kalianyar, saluran Primer Sumargo, saluran Sekunder Pahlawan, dan saluran Primer Andan Wangi yang dapat dilihat pada gambar 1 .

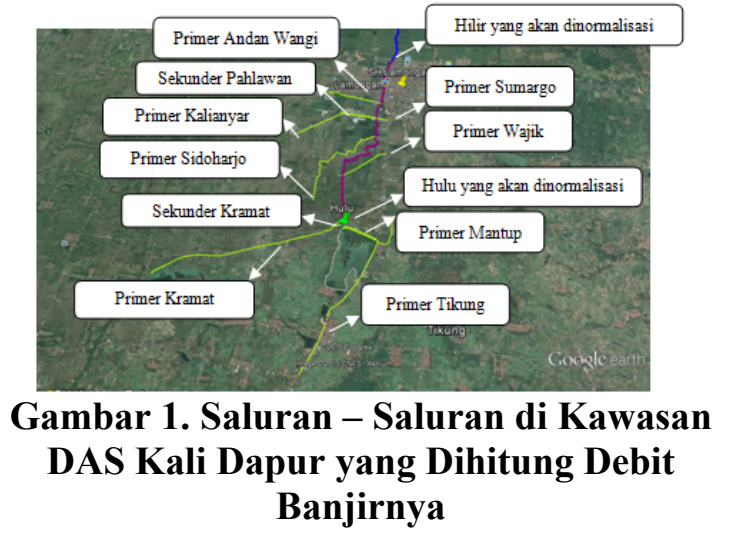

Langkah pertama yang dilakukan untuk menghitung debit ialah menghitung tinggi hujan jam - jaman. Selanjutnya ialah dengan menghitung nilai $\mathrm{C}$ gabungan dari tiap saluran. Nilai C gabungan pada saluran primer dan sekunder tahun 2011 dan tahun 2031 dapat dilihat pada tabel 4 dan tabel 5 .

Tabel 4. Data dan Perhitungan $C_{\text {Gabungan }} d i$ Saluran Primer dan Sekunder Tahun 2011

\begin{tabular}{|c|c|c|c|c|c|c|c|c|c|c|}
\hline \multirow[t]{2}{*}{ No } & \multirow[t]{2}{*}{ Saluran } & \multirow{2}{*}{\begin{tabular}{|c|}
$\begin{array}{c}\text { Luas } \\
\text { Pemuki- } \\
\text { man }\end{array}$ \\
$\mathrm{km}^{2}$ \\
\end{tabular}} & \multirow[t]{2}{*}{$\begin{array}{c}\mathrm{C} \\
\text { pemuki- } \\
\text { man }\end{array}$} & $\begin{array}{l}\text { Luas } \\
\text { Jalan }\end{array}$ & \multirow{2}{*}{ C jln } & \multirow{2}{*}{\begin{tabular}{|c|} 
Luas \\
Lahan \\
Hijau \\
$\mathrm{km}^{2}$ \\
\end{tabular}} & \multirow[t]{2}{*}{$\underset{\text { lahan }}{\mathrm{C}}$} & \multirow[t]{2}{*}{$\begin{array}{c}\text { Sig } \\
\text { CiAi }\end{array}$} & \multirow[t]{2}{*}{ Sig Ai } & \multirow[t]{2}{*}{ C gab } \\
\hline & & & & $\mathrm{km}^{2}$ & & & & & & \\
\hline 1 & Primer Kramat & \begin{tabular}{|l|}
0.8435 \\
\end{tabular} & 0.6 & 0.0635 & 0.85 & 10.57 & 0.25 & 3.202 & 11.476 & 0.28 \\
\hline 2 & \begin{tabular}{|l} 
Primer Tikung \\
\end{tabular} & 0.5437 & 0.6 & 0.0409 & 0.85 & 5.93 & 0.25 & 1.842 & 6.511 & 0.28 \\
\hline 3 & Sekunder Kramat & 0.0061 & 0.6 & 0.0005 & 0.85 & 0.01 & 0.25 & 0.006 & 0.014 & 0.43 \\
\hline 4 & Primer Mantup & 0.0346 & 0.6 & 0.0026 & 0.85 & 1.12 & 0.25 & 0.304 & 1.160 & 0.26 \\
\hline 5 & Primer Sidoharjo & 0.1966 & 0.6 & 0.0148 & 0.85 & 3.97 & 0.25 & 1.124 & 4.183 & 0.27 \\
\hline 6 & Primer Wajik & 0.0000 & 0.6 & 0.0000 & 0.85 & 0.47 & 0.25 & 0.116 & \begin{tabular}{|l|}
0.466 \\
\end{tabular} & 0.25 \\
\hline 7 & Primer Sumargo & 0.1358 & 0.6 & 0.0102 & 0.85 & 0.36 & 0.25 & 0.180 & 0.505 & 0.36 \\
\hline 8 & Sekunder Pahlawan & 0.0334 & 0.6 & 0.0025 & 0.85 & 0.14 & 0.25 & 0.058 & \begin{tabular}{|l|}
0.177 \\
\end{tabular} & 0.32 \\
\hline 9 & \begin{tabular}{|l|} 
Primer Kalianyar \\
\end{tabular} & 0.6053 & 0.6 & 0.0456 & 0.85 & 0.60 & 0.25 & 0.553 & \begin{tabular}{|l|}
1.254 \\
\end{tabular} & 0.44 \\
\hline 10 & Primer Andan Wangi & 0.2278 & 0.6 & 0.0171 & 0.85 & 0.97 & 0.25 & 0.394 & 1.216 & 0.32 \\
\hline 11 & Primer Delanggu & 0.3736 & 0.6 & 0.0281 & 0.85 & 5.03 & 0.25 & 1.505 & 5.430 & 0.28 \\
\hline 12 & Primer G.Boyo Untung & 0.1321 & 0.6 & 0.0099 & 0.85 & 0.79 & 0.25 & 0.286 & \begin{tabular}{|l|}
0.936 \\
\end{tabular} & 0.31 \\
\hline
\end{tabular}

Tabel 5. Data dan Perhitungan $\mathrm{C}_{\text {Gabungan }} \mathrm{di}$ Saluran Primer dan Sekunder Tahun 2031

\begin{tabular}{|c|c|c|c|c|c|c|c|c|c|c|}
\hline \multirow[t]{2}{*}{ No } & \multirow[t]{2}{*}{ Saluran } & \multirow{2}{*}{\begin{tabular}{|c|}
$\begin{array}{c}\text { Luas } \\
\text { Pemuki- } \\
\text { man }\end{array}$ \\
$\mathrm{km}^{2}$ \\
\end{tabular}} & \multirow{2}{*}{$\begin{array}{c}\mathrm{C} \\
\text { pemuki- } \\
\text { man }\end{array}$} & \begin{tabular}{|l|} 
Luas \\
Jalan \\
\end{tabular} & \multirow{2}{*}{ C jln } & \multirow{2}{*}{\begin{tabular}{|c|c|}
$\begin{array}{c}\text { Luas } \\
\text { Lahan }\end{array}$ \\
$\mathrm{km}^{2}$ \\
\end{tabular}} & \multirow[t]{2}{*}{$\begin{array}{c}\mathrm{C} \\
\text { lahan }\end{array}$} & \multirow[t]{2}{*}{$\begin{array}{c}\mathrm{Sig} \\
\mathrm{CiAi}\end{array}$} & \multirow{2}{*}{\begin{tabular}{|l}
$\mathrm{Sig} \mathrm{Ai}$ \\
$\mathrm{km}^{2}$ \\
\end{tabular}} & \multirow[t]{2}{*}{ C gab } \\
\hline & & & & $\mathrm{km}^{2}$ & & & & & & \\
\hline 1 & Primer Kramat & \begin{tabular}{|l|}
0.8435 \\
\end{tabular} & 0.6 & 0.0635 & \begin{tabular}{|l|}
0.85 \\
\end{tabular} & 10.57 & 0.25 & 3.202 & \begin{tabular}{|l|l|}
11.476 \\
\end{tabular} & 0.28 \\
\hline 2 & Primer Tikung & 0.5437 & 0.6 & 0.0409 & 0.85 & 5.93 & 0.25 & 1.842 & 6.511 & 0.28 \\
\hline 3 & Sekunder Kramat & 0.0061 & 0.6 & 0.0005 & \begin{tabular}{|l|}
0.85 \\
\end{tabular} & 0.01 & 0.25 & 0.006 & 0.014 & 0.43 \\
\hline 4 & Primer Mantup & 0.0346 & 0.6 & 0.0026 & 0.85 & 1.12 & 0.25 & 0.304 & 1.160 & 0.26 \\
\hline 5 & Primer Sidoharjo & 0.1966 & 0.6 & 0.0148 & \begin{tabular}{|l|}
0.85 \\
\end{tabular} & 3.97 & 0.25 & 1.124 & 4.183 & 0.27 \\
\hline 6 & Primer Wajik & 0.0000 & 0.6 & 0.0000 & \begin{tabular}{|c|}
0.85 \\
\end{tabular} & 0.47 & 0.25 & 0.116 & 0.466 & 0.25 \\
\hline 7 & Primer Sumargo & 0.1358 & 0.6 & 0.0102 & \begin{tabular}{|l|}
0.85 \\
\end{tabular} & 0.36 & 0.25 & 0.180 & 0.505 & 0.36 \\
\hline 8 & Sekunder Pahlawan & 0.0334 & 0.6 & 0.0025 & 0.85 & 0.14 & 0.25 & 0.058 & 0.177 & 0.32 \\
\hline 9 & \begin{tabular}{|l|} 
Primer Kalianyar \\
\end{tabular} & 0.6053 & 0.6 & 0.0456 & \begin{tabular}{|l|}
0.85 \\
\end{tabular} & 0.60 & 0.25 & 0.553 & 1.254 & 0.44 \\
\hline 10 & Primer Andan Wangi & 0.2968 & 0.6 & 0.0223 & \begin{tabular}{|l|}
0.85 \\
\end{tabular} & 0.90 & 0.25 & 0.421 & 1.216 & 0.35 \\
\hline 11 & Primer Delanggu & 0.4749 & 0.6 & 0.0357 & \begin{tabular}{|l|l|}
0.85 \\
\end{tabular} & 4.92 & 0.25 & 1.545 & 5.430 & 0.28 \\
\hline 12 & Primer G.Boyo Untung & 0.1321 & 0.6 & 0.0099 & 0.85 & 0.79 & 0.25 & 0.286 & 0.936 & 0.31 \\
\hline
\end{tabular}

Setelah nilai $\mathrm{C}$ gabungan diketahui, maka langkah selanjutnya ialah menghitung hidrograf satuan sintetik (HSS) Snyder - Alexejev. Berikut ialah contoh perhitungan HSS Snyder Alexejev di saluran Primer Tikung tahun 2011 2031 :

$$
\begin{aligned}
& \mathrm{Ct}=0,08 \\
& \mathrm{Cp}=0,69 \\
& \mathrm{~L}=3,205 \mathrm{~km} \\
& \mathrm{Lc}=1,603 \mathrm{~km} \\
& \text { A } \quad=6,511 \mathrm{~km}^{2} \\
& \Delta \mathrm{H}=0,017 \mathrm{~km} \\
& \mathrm{~S}=\frac{\Delta \mathrm{H}}{L}=\frac{0,017}{3,205}=0,0053 \\
& \text { tp }=C t\left(\frac{L x L c}{\sqrt{S}}\right)^{0,38}=0,08\left(\frac{3,205 \times 1,603}{\sqrt{0,0053}}\right)^{0,38} \\
& \text { te }=\frac{\mathrm{tp}}{5,5}=\frac{0,403}{5,5} \quad \begin{array}{l}
=, 403 \mathrm{jam} \\
=0,073 \mathrm{jam}
\end{array} \\
& \operatorname{tr} \quad=1 \mathrm{jam}
\end{aligned}
$$

Karena te $<\operatorname{tr}$ maka $T p=\operatorname{tp}+0,5$

$$
\begin{aligned}
\mathrm{Tp} & =0,403+0,5 \\
& =0,903 \mathrm{jam} \\
\mathrm{qp} & =0,278 \frac{C p}{T p}=0,278 \frac{0,69}{0,903} \\
& =0,212 \mathrm{~m}^{3} / \mathrm{det} / \mathrm{km}^{2} \\
\mathrm{Qp} & =\mathrm{qp} \times \mathrm{A}=0,212 \times 6,511 \\
& =1,383 \mathrm{~m}^{3} / \mathrm{det}
\end{aligned}
$$

(untuk hujan $1 \mathrm{~mm} /$ jam)

Ordinat - ordinat hidrograf satuan dihitung dengan persamaan Alexejev, yaitu :

$$
\begin{aligned}
\mathrm{Y} & =\mathrm{Q} / \mathrm{Qp} \\
\mathrm{X} & =\mathrm{t} / \mathrm{Tp} \\
\mathrm{Y} & =10^{-a \frac{(1-x)^{2}}{x}} \\
\lambda & =\frac{Q p T p}{h A}=\frac{1,383 \times 0,903}{1 \times 6,511}=0,192 \\
\mathrm{a} & =1,32 \lambda^{2}+0,15 \lambda+0,045 \\
& =1,32(0,192)^{2}+0,15(0,192)+0,045 \\
& =0,122
\end{aligned}
$$


Perhitungan hidrograf Snyder - Alexejev di saluran Primer Tikung dapat dilihat pada gambar di bawah ini.

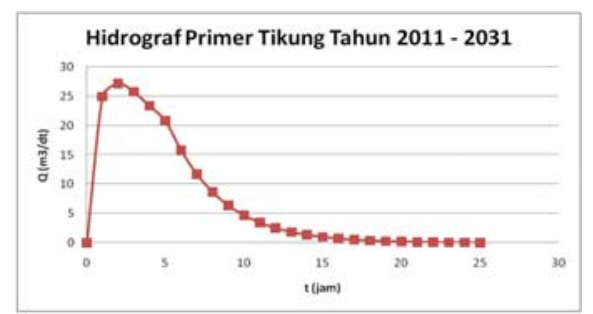

Gambar 2. HSS Snyder - Alexejev di Hulu Kali Dapur Tahun 2011 - 2031

Dengan cara yang sama, dilakukan perhitungan pada saluran - saluran lain yang menuju Kali Dapur.

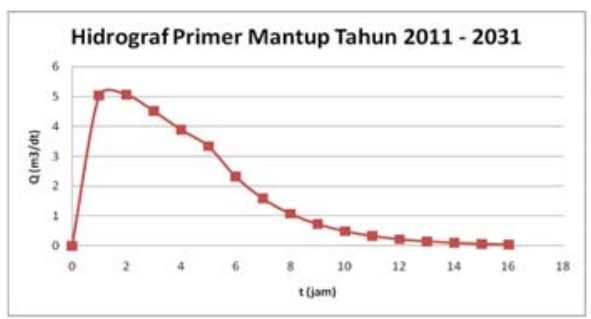

Gambar 3. HSS Snyder - Alexejev Saluran Primer Mantup Tahun 2011 - 2031

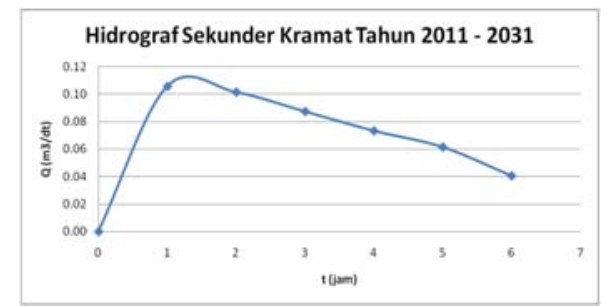

Gambar 4. HSS Snyder - Alexejev Saluran Sekunder Kramat Tahun 2011 - 2031

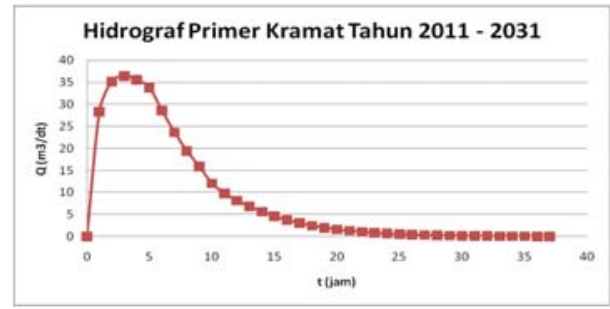

Gambar 5. HSS Snyder - Alexejev Saluran Primer Kramat Tahun 2011 - 2031

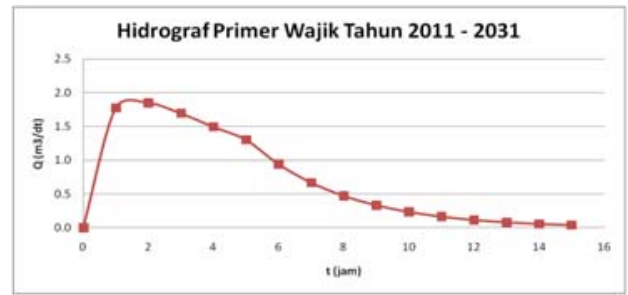

Gambar 6. HSS Snyder - Alexejev Saluran Primer Wajik Tahun 2011 - 2031

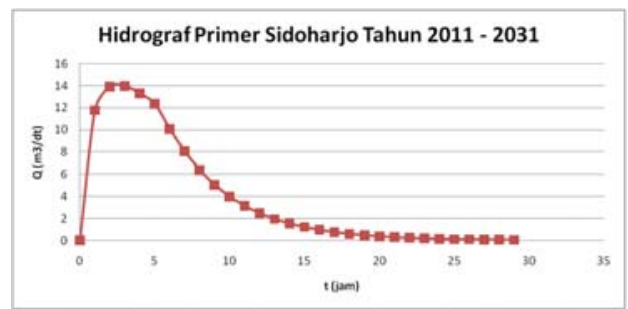

Gambar 7. HSS Snyder - Alexejev Saluran Primer Sidoharjo Tahun 2011 - 2031

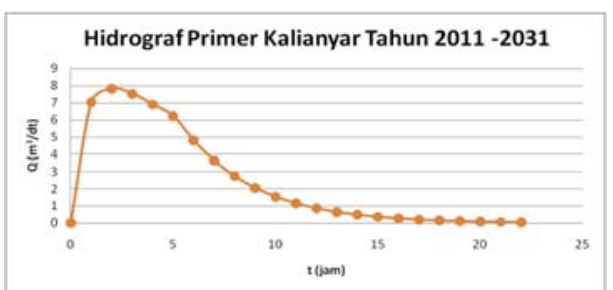

Gambar 8. HSS Snyder - Alexejev Saluran Primer Kalianyar Tahun 2011 - 2031

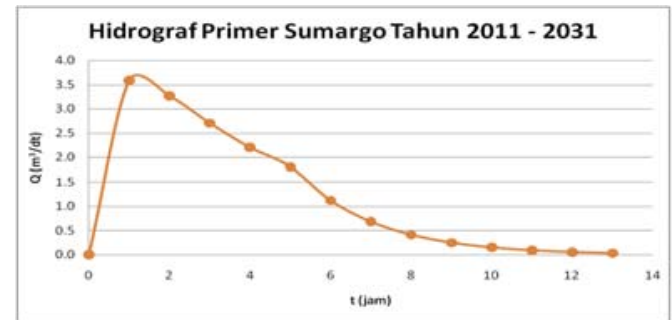

Gambar 9. HSS Snyder - Alexejev Saluran Primer Sumargo Tahun 2011 - 2031

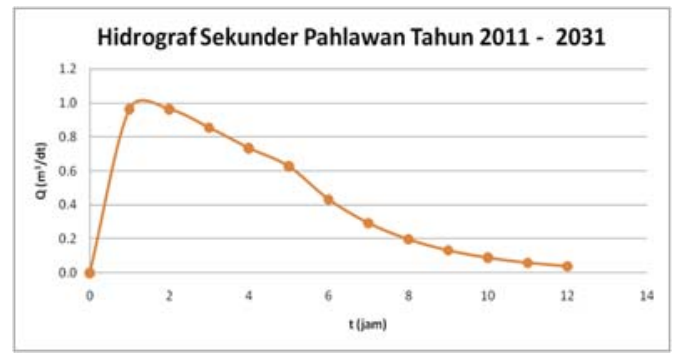

Gambar 10. HSS Snyder - Alexejev Saluran Sekunder Pahlawan Tahun 2011 - 2031 
Perkembangan Kota Lamongan

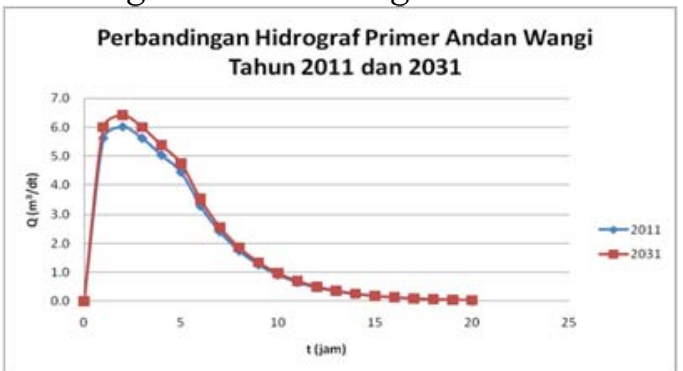

Gambar 11. HSS Snyder - Alexejev Saluran Primer Andan Wangi Tahun 2011 dan Tahun 2031

D. Analisa Hidrolika

Analisa Routing Debit Banjir di Waduk Jotosanur

Waduk Jotosanur ialah waduk yang terletak di bagian hulu Kali Dapur dan menerima inflow dari saluran Primer Tikung dan saluran Primer Mantup. Pintu waduk memiliki lebar $80 \mathrm{~cm}$. Perhitungan routing menggunakan bukaan pintu maksimal sebesar $60 \mathrm{~cm}$ dan jenis aliran tak tenggelam dapat dilihat pada tabel 6 . Lengkung elevasi waduk Jotosanur dapat dilihat pada gambar 12. Sedangkan perhitungan rating curve aliran tak tenggelam yang menggambarkan antara tinggi muka air di depan pintu $\left(\mathrm{h}_{1}\right)$ dengan debit pintu (Q) dapat dilihat pada gambar 13.

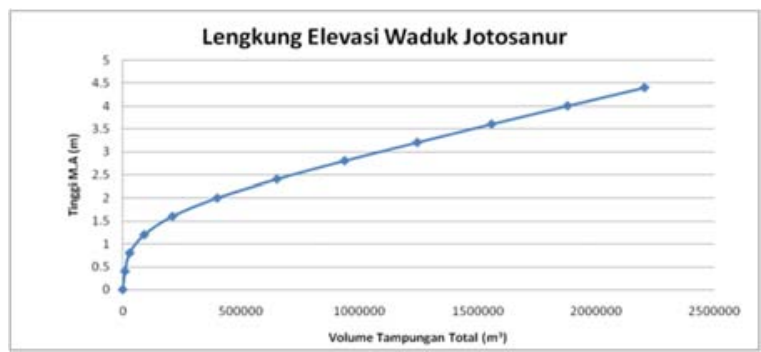

Gambar 12. Grafik Lengkung Elevasi Muka Air dengan Volume Waduk Tampung

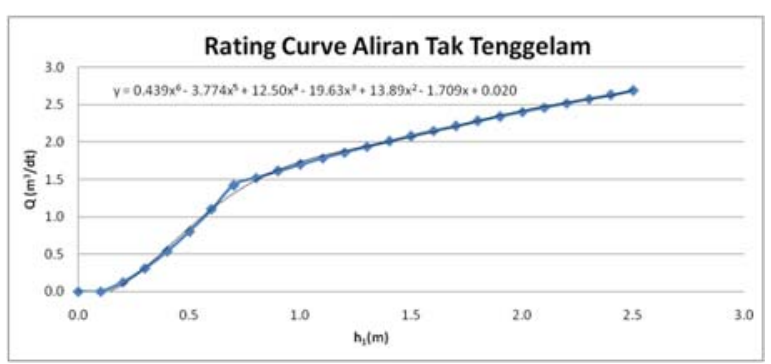

Gambar 13. Rating Curve Aliran Tak Tenggelam
Tabel 6. Perhitungan Routing Waduk

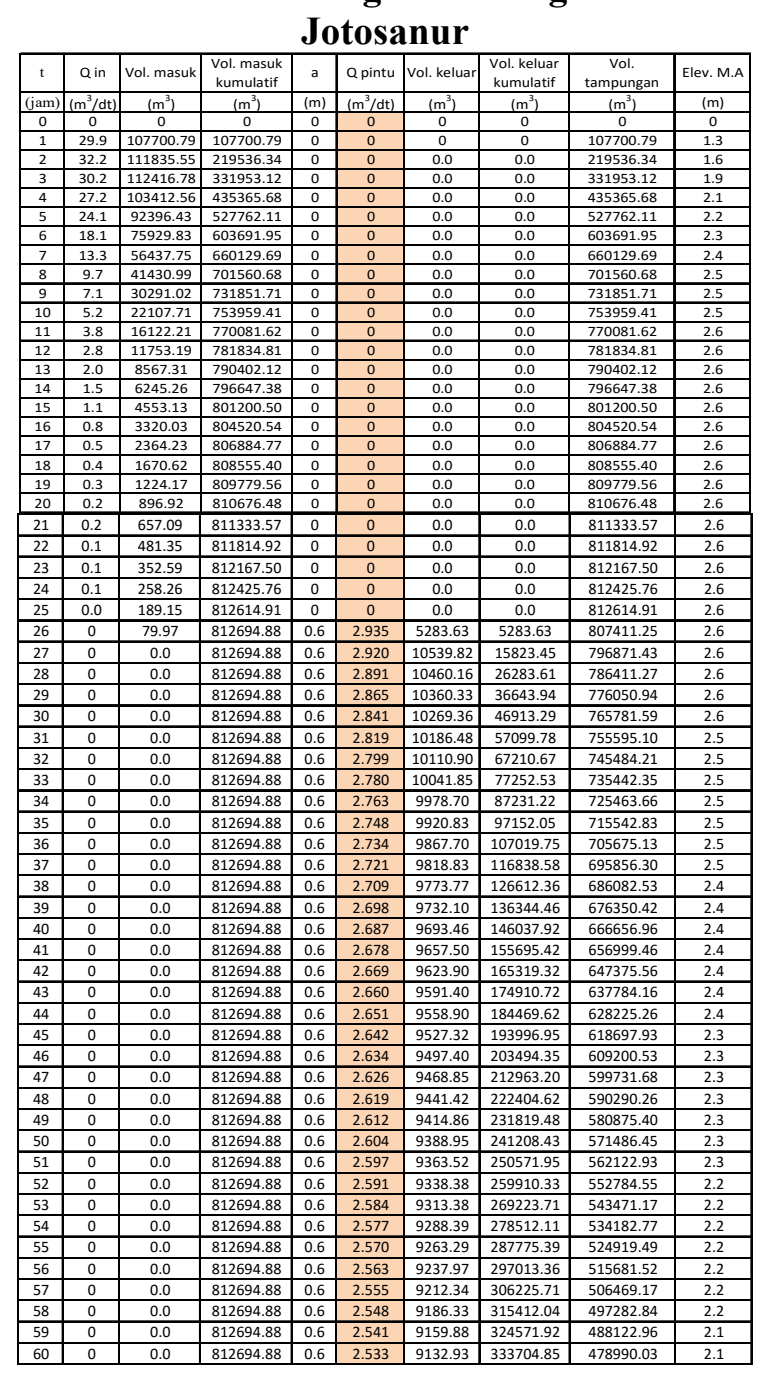

- Analisa Kapasitas Waduk Rancang

Waduk Rancang berfungsi untuk membantu saluran Primer Kramat dalam menampung debit banjir. Jika pada perhitungan sebelumnya pada gambar 5, saluran Primer Kramat memiliki catchment area sebesar $11,476 \mathrm{~km}^{2}$. Maka dengan adanya waduk Rancang, catchment area saluran Primer Kramat berkurang menjadi 4,691 $\mathrm{km}^{2}$. Waduk Rancang menerima limpasan dari saluran sekunder Mojomanis. Perhitungan volume limpasan saluran sekunder Mojomanis dapat dilihat pada tabel 7 .

Tabel 7. Perhitungan Volume Limpasan Sekunder Mojomanis Tahun 2011 - 2031 


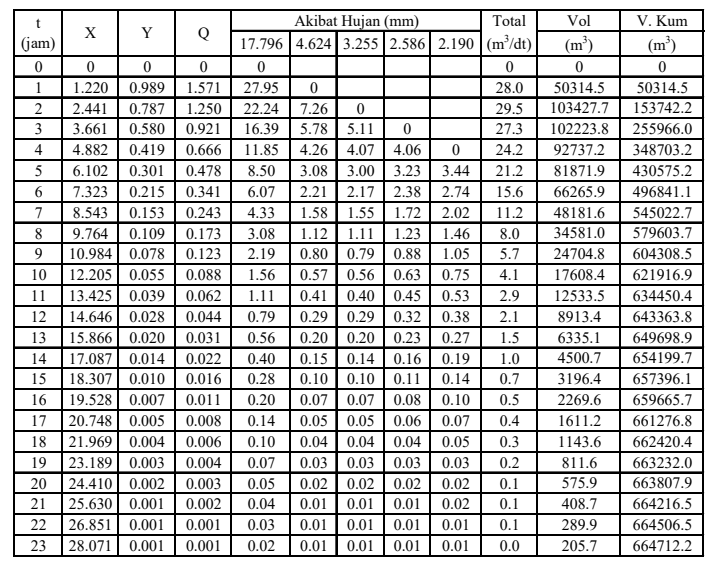

Sedangkan perhitungan kapasitas waduk Rancang dapat dilihat pada tabel 8. Kapasitas waduk Rancang dihitung berdasarkan kontur di daerah waduk Rancang.

Dari tabel 8, diketahui bahwa volume tampung waduk Rancang sebesar $1.606 .837 \mathrm{~m}^{3}$. Dengan volume tampung tersebut, maka waduk Rancang mampu menerima volume limpasan dari saluran Sekunder Mojomanis pada tabel 7 yaitu sebesar $664.712,2 \mathrm{~m}^{3}$.

Tabel 8. Perhitungan Volume Tampung Waduk Rancang

\begin{tabular}{|c|c|c|c|c|}
\hline Elevasi & Tinggi M.A & $\begin{array}{c}\text { Luas } \\
\text { Kolam }\end{array}$ & $\begin{array}{c}\text { Volume } \\
\text { Tampung }\end{array}$ & $\begin{array}{c}\text { Volume } \\
\text { Tampung }\end{array}$ \\
\hline$(\mathrm{m})$ & $(\mathrm{m})$ & $\left(\mathrm{m}^{2}\right)$ & $\left(\mathrm{m}^{3}\right)$ & $\left(\mathrm{m}^{3}\right)$ \\
\hline 8.8 & 0 & 0 & 0 & 0 \\
\hline 9.6 & 0.8 & 6091.25 & 4873.0026 & 4873.00262 \\
\hline 10.4 & 1.6 & 117043 & 93634.343 & 98507.3451 \\
\hline 11.2 & 2.4 & 256169 & 204935 & 303442.344 \\
\hline 12 & 3.2 & 327760 & 262208.12 & 565650.465 \\
\hline 12.8 & 4 & 397896 & 318317.08 & 883967.541 \\
\hline 13.6 & 4.8 & 442474 & 353979.33 & 1237946.87 \\
\hline 14.4 & 5.6 & 461113 & 368890.74 & 1606837.6 \\
\hline
\end{tabular}

- Analisa Penampang Eksisting Kali Dapur Hasil simulasi Hec - Ras untuk penampang eksisting Kali Dapur dapat dilihat pada gambar 14.

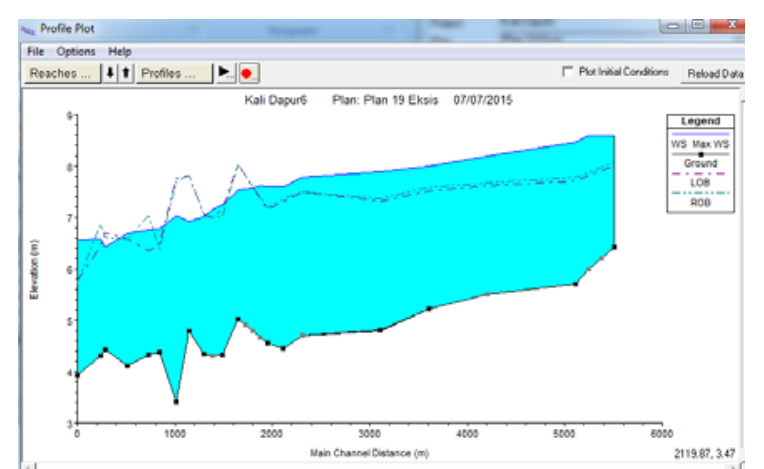

Gambar 14. Profil Muka Air Maksimum pada Penampang Eksisting Kali Dapur / Otik
Jika dilihat pada gambar 14, LOB dan ROB merupakan tinggi tanggul bagian kiri dan kanan dari saluran. Dari gambar 14, dapat dilihat bahwaprofil muka air masih banyak yang melebihi tanggul. Hal ini menunjukkan penampang eksisting banyak yang belum mampu menampung debit banjir yang terjadi.

- Analisa Penampang Normalisasi Kali Dapur Hasil simulasi Hec - Ras untuk penampang normalisasi Kali Dapur dapat dilihat pada gambar 15.

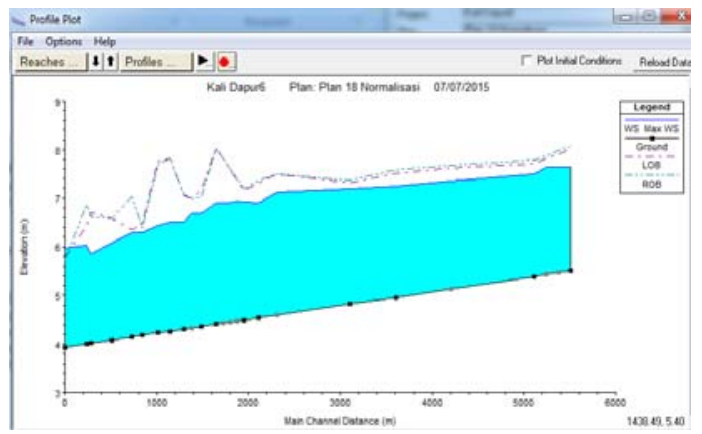

Gambar 15. Profil Muka Air Maksimum pada

Penampang Normalisasi Kali Dapur / Otik

Setelah normalisasi, penampang sudah mampu menampung debit banjir. Namun, belum memenuhi syarat tinggi jagaan minimal sebesar $0,5 \mathrm{~m}$.

- Analisa Penampang Normalisasi Setelah Adanya Pengaruh Boezem

Untuk membantu penampang normalisasi Kali Dapur dalam memenuhi syarat tinggi jagaan sebesar $0,5 \mathrm{~m}$ maka diperlukan suatu tindakan yaitu dengan membangun sebuah boezem di saluran Primer Sidoharjo. Kebutuhan volume boezem untuk perencanaan dihitung dengan menggunakan selisih luasan area dari hidrograf di saluran Primer Sidoharjo dengan hidrograf trial and error. Dari selisih luasan area kedua hidrograf tersebut, akan diperoleh besaran volume boezem yang dibutuhkan untuk perencanaan.

Selisih luasan area antara hidrograf di saluran Primer Sidoharjo dengan hidrograf trial and error dapat dilihat pada gambar 16 . 
Perkembangan Kota Lamongan

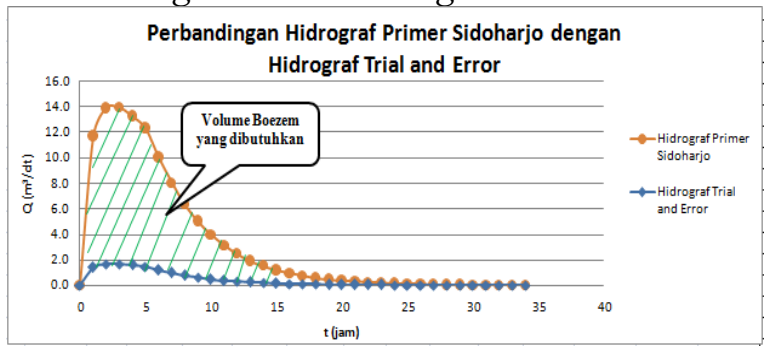

Gambar 16. Luasan Area yang Dihitung untuk Mendapatkan Besarnya Volume Boezem yang Dibutuhkan

Dari gambar 16, dapat diketahui besarnya volume boezem yang dibutuhkan untuk perencanaan ialah sebesar 359408,74 $\mathrm{m}^{3}$. Direncanakan boezem dengan data sebagai berikut :

Luasan boezem rencana $(\mathrm{A})= \pm 144837 \mathrm{~m}^{2}$ Kedalaman boezem rencana (d) $\quad=2,5 \mathrm{~m}$ sehingga boezem memiliki kapasitas tampungan sebesar :

$$
\begin{aligned}
V_{\text {boezem }} & =\mathrm{A} \times \mathrm{d}=144837 \times 2,5 \\
& =362092,5 \mathrm{~m}^{3}>\mathrm{V}_{\text {butuh }}=359408,74 \mathrm{~m}^{3}
\end{aligned}
$$

Hasil simulasi Hec - Ras untuk penampang normalisasi setelah adanya pengaruh boezem dapat dilihat pada gambar 17 .

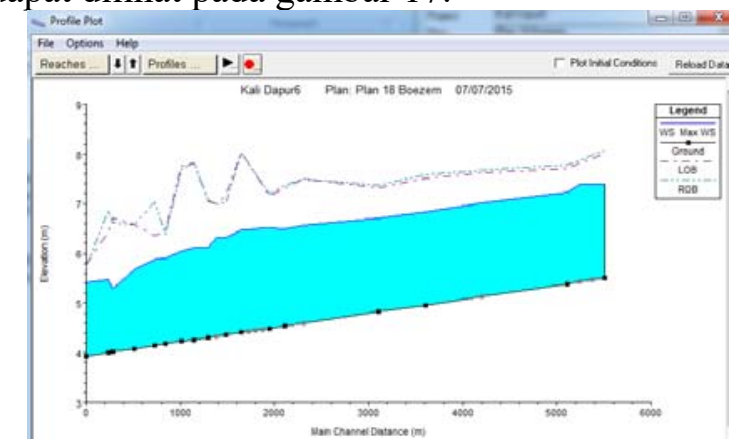

Gambar 17. Profil Muka Air Maksimum pada Penampang Normalisasi Kali Dapur / Otik Setelah Adanya Pengaruh Boezem

Jika dilihat pada gambar 17, boezem di saluran Primer Sidoharjo mampu membantu penampang normalisasi Kali Dapur dalam memenuhi syarat tinggi jagaan minimal sebesar $0,5 \mathrm{~m}$.

\section{KESIMPULAN}

1. Kali Dapur / Otik memiliki luas daerah aliran sungai (DAS) sebesar $\pm 32.797 .378,61$ $\mathrm{m}^{2}$.
2. Tidak terdapat banyak perbedaan besaran nilai koefisien pengaliran (C) di daerah aliran sungai (DAS) Kali Dapur / Otik pada tahun 2011 dan pada tahun 2031. Perubahan hanya terlihat pada luas pemukiman di catchment area Primer Andan Wangi dan Primer Delanggu tahun 2031 yang sedikit lebih besar dibanding dengan luas pemukiman pada tahun 2011. Oleh karena itu, perubahan tata guna lahan yang terjadi tidak terlalu berpengaruh banyak pada besarnya nilai koefisien pengaliran (C). Perbandingan nilai koefisien pengaliran (C) pada tahun 2011 dan 2031 dapat dilihat pada tabel 9.

Tabel 9. Perbandingan Nilai Koefisien Pengaliran (C) di Saluran Primer dan Sekunder

\begin{tabular}{|c|l|c|c|}
\hline \multirow{2}{*}{ No } & \multicolumn{2}{|c|}{ Saluran } & \multicolumn{2}{|c|}{ Debit maksimum $\left(\mathrm{m}^{3} / \mathrm{dt}\right)$} \\
\cline { 3 - 4 } & & 2011 & 2031 \\
\hline 1 & Primer Kramat & 13.7 & 13.7 \\
\hline 2 & Primer Tikung & 27.2 & 27.2 \\
\hline 3 & Sekunder Kramat & 0.1 & 0.1 \\
\hline 4 & Primer Mantup & 5.1 & 5.1 \\
\hline 5 & Primer Sidoharjo & 14.0 & 14.0 \\
\hline 6 & Primer Wajik & 1.8 & 1.8 \\
\hline 7 & Primer Sumargo & 3.6 & 3.6 \\
\hline 8 & Sekunder Pahlawan & 1.0 & 1.0 \\
\hline 9 & Primer Kalianyar & 7.8 & 7.8 \\
\hline 10 & Primer Andan Wangi & 6.0 & 6.4 \\
\hline \multirow{2}{*}{ No } & & \multicolumn{2}{|c|}{ Nilai C gab } \\
\cline { 2 - 4 } & & 2011 & 2031 \\
\hline 1 & Primer Kramat & 0.28 & 0.28 \\
\hline 2 & Primer Tikung & 0.28 & 0.28 \\
\hline 3 & Sekunder Kramat & 0.43 & 0.43 \\
\hline 4 & Primer Mantup & 0.26 & 0.26 \\
\hline 5 & Primer Sidoharjo & 0.27 & 0.27 \\
\hline 6 & Primer Wajik & 0.25 & 0.25 \\
\hline 7 & Primer Sumargo & 0.36 & 0.36 \\
\hline 8 & Sekunder Pahlawan & 0.32 & 0.32 \\
\hline 9 & Primer Kalianyar & 0.44 & 0.44 \\
\hline 10 & Primer Andan Wangi & 0.32 & 0.35 \\
\hline 11 & Primer Delanggu & 0.28 & 0.28 \\
\hline 12 & Primer G.Boyo Untung & 0.31 & 0.31 \\
\hline
\end{tabular}

3. Besaran debit banjir maksimum pada tahun 2011 dan tahun 2031 dapat dilihat pada tabel 10.

\section{Tabel 10. Perbandingan Nilai Debit Maksimum di Saluran Primer dan Sekunder}

4. Penampang eksisting Kali Dapur belum mampu menampung debit banjir yang terjadi sehingga perlu dilakukan normalisasi sungai. 
Pelaksanaan normalisasi dilakukan dengan ketentuan - ketentuan sebagai berikut :

a. Normalisasi dilakukan dengan merapikan seluruh bentuk penampang menjadi bentuk persegi.

b. Normalisasi tidak dilakukan dengan melebarkan saluran ke kanan atau kiri, melainkan dengan melakukan penggalian sehingga saluran lebih dalam.

c. Elevasi dasar saluran di hilir setelah normalisasi sengaja tidak diubah agar tidak memengaruhi aliran di Kali Dapur secara keseluruhan.

d. Kemiringan sungai dibuat sama rata sehingga tidak ada elevasi dasar saluran yang naik turun.

5. Penampang Kali Dapur setelah normalisasi sudah mampu menampung debit banjir. Namun penampang normalisasi belum memenuhi syarat tinggi jagaan $0,5 \mathrm{~m}$. Oleh karena itu, diperlukan sebuah tindakan untuk membantu Kali Dapur dalam memenuhi syarat tinggi jagaan. Tindakan yang dilakukan ialah dengan merencanakan sebuah boezem di saluran Primer Sidoharjo dengan kebutuhan volume tampungan sebesar 359408,74 $\mathrm{m}^{3}$. Oleh karena itu direncanakan sebuah boezem dengan luasan sekitar $\pm 144837 \mathrm{~m}^{2}$ dengan kedalaman $3 \mathrm{~m}$.

\section{DAFTAR PUSTAKA}

[1] Chow, V.T., Maidment, D.R and Mays, L.W., 1988. Applied Hydrology. Mc. Graw Hill International Edition. Civil Engineering Series.

[2] Direktorat Jendral Departemen Pekerjaan Umum, Standar Perencanaan Irigasi Kriteria Perencanaan 02, Badan Penerbit Departemen Pekerjaan Umum, Jakarta,1986.

[3] Harto S, 1993. Analisis Hidrologi. Gramedia Pustaka Utama, Jakarta.

[4] Schulz, E.F. 1978. Problems in Applied Hydrology. Water Resources Publication. Colorado.

[5] Soemarto, C.D. 1995. Hidrologi Teknik (Edisi ke-2). Erlangga. Jakarta.

[6] Soemarto, C.D. 1999. Hidrologi Teknik. Jakarta : Erlangga.

[7] Soewarno. 1995. Hidrologi Aplikasi Metode Statistik untuk Analisa Data Jilid 1. Nova. Bandung.

[8] Subramanya, K. 1995. Engineering Hydrology. TATA McGRAW - HILL Publishing Company Limited, 2nd Edition, New Delhi.

[9] Suripin. 2004. Sistem Drainase Perkotaan yang Berkelanjutan. Andi. Yogyakarta. 